\title{
ELOGIO DE GÓRGIAS
}

\author{
ADMA MUHANA* \\ Instituto de Estudos da Linguagem \\ da Universidade Estadual de Campinas
}

\begin{abstract}
RESUMO: Tem este texto por objetivo evidenciar relações que Aristóteles estabelece entre a poesia, a retórica e a sofística, principalmente na Poética, na Retórica enos Elencos sofísticos, confrontando-as com o que transparece dos escritos de Górgias, sobretudo o Elogio de Helena. O ponto de partida é um rol de procedimentos da linguagem - isto é, da léxis e não do logos - que, tanto na Poética como nos Elencos, Aristóteles identifica como sendo distintos dos da dialética. Nas duas obras, a lista de procedimentos é idêntica, mas, em um caso (na Poética), eles são legitimados em termos da propriedade elocutiva da poesia e, no outro (nos Elencos), são rejeitados como fazendo parte das falácias sofísticas.
\end{abstract}

PALAVRAS-CHAVE: sofística; retórica; dialética; poética.

Conhecemos há muito a célebre sentença de Aristóteles, segundo a qual a poesia está próxima da filosofia por se referir ao universal, entendendo ele por "referirse ao universal" a atribuição, a um particular, de ações e pensamentos que, por necessidade e verossimilhança, pertencem à sua natureza (Poética, IX, 1451b 3-8). Nesse logos ou razão poética, a constituição da verossimilhança dá-se pela coerência interna de suas partes, de modo que a unidade da obra poética corresponda a uma unidade de sentido, que, não sendo verdadeira, é verossímil, ou semelhante à verdade. $O$ termo que Aristóteles utiliza para designar esse verossímil assim pensado é eikos: semelhança, aparência. Na poesia, eikos e logos se equivalem.

Isso também ocorre na dialética, embora por razões diversas. Na dialética, a unidade e, portanto, a universalidade, está na adequação entre a linguagem, que expressa o pensamento, e as coisas, sendo o problema aristotélico constituir tal adequação, em termos tanto dos nomes, como das proposições e dos enunciados ou discursos. Em todos os seus tratados - no Da interpretação, nos Segundos Analíticos, nos Tópicos, na Metafísica - Aristóteles se nos depara com a questão: como saber, pelas palavras, se 
o que alguém pensa é o mesmo que o outro pensa? A dificuldade, diz ele no Da Interpretação, é que não há uma palavra para cada coisa e que, entre a coisa e as universais afecções da alma, há sempre os signos, falados ou escritos. Então, entre a coisa e a palavra, que é signo da coisa, há sempre um desvio e, entre o signo e o pensamento da coisa, outro desvio. As palavras, estas, são signos ou símbolos das afecções da alma; assemelham-se às coisas e ao pensamento, mas não são o mesmo que eles. Então, a dificuldade reside não tanto nas coisas (Aristóteles se esmera em classificá-las), como também não nas almas (seus modos de pensar e serem afetadas por sensações, fantasias e fenômenos são igualmente catalogáveis, universalmente); a dificuldade está nas palavras e em sua reunião, que não são as mesmas nem isoladamente nem em conjunto, nem para todos os homens. A dificuldade está em saber como as palavras, cada uma por si, cada proposição e cada enunciado ou discurso (a Ilíada, por exemplo), podem ser una e dizerem adequadamente uma única coisa. ${ }^{1}$

O mesmo deveria ocorrer na retórica. Sabemos que a coalizão proposta por Platão entre a retórica, a poesia e a sofística, de um lado, e a filosofia, de outro, é o solo a partir do qual Aristóteles ergue sua Retórica, para nela estabelecer contudo as condições que a dignificam como uma retórica "dialética", em contraposição à sofística. ${ }^{2}$ Neste sentido, toda a taxinomia de provas (argumentativas e ético-patéticas) expostas nos Livros I e II da Retórica como sua matéria própria aparece como o conjunto dos meios persuasivos legítimos de que o orador se vale para se tornar algo distinto de um poeta e de um sofista - que, cada um a seu modo, dizem palavras e sentenças com significação diversa da da ordem das coisas, que usam dos afetos de modo a obscurecer sua forma (substancial) sob cores (acidentais), e que sabem enfim como dizer o falso. ${ }^{3}$ Daí a grande ênfase, na Retórica, não só nas provas argumentativas - que promovem um encadeamento dialético do discurso válido mesmo na ausência de sua atualização oral -, mas também nas éticopatéticas, no sentido de estabelecer minuciosas regulações visando ao seu controle. Aristóteles afirma que é preciso não só estar de posse das provas, mas saber apresentá-las, pelas palavras, de modo que elas tenham tal ou qual caráter, isto é, afetem de tal ou qual maneira (Retórica, III, 1, 1403b 11-12). Ou seja, depois de apreender as razões, o logos, é preciso saber pronunciá-las e animá-las com os afetos e os caracteres que lhes correspondem - vesti-las com léxis. A unidade do discurso dar-se-á - e desse modo semelhantemente à poética - na adequação entre provas técnicas (dialéticas e ético-patéticas), isto é, logos e verossímil.

Todavia, as diferentes finalidades dos discursos dialético, retórico e poético propõem logoi distintos, que distinguem reciprocamente o uso da léxis em cada um deles. Em todos, propõe-se uma unidade, mas, na dialética, visa-se a uma unidade em que a léxis seja a expressão imediata do próprio logos, por se dirigir à apreensão da verdade; na 
retórica, a unidade, para redundar em persuasão, exige do discurso que comporte afetos e caracteres; na poesia, finalmente, a unidade, para constituir o verossímil, faz com que o discurso, além da persuasão retórica, comporte assunção e extirpação de afetos. Então, em cada um desses discursos, a unidade formada por léxis e logos há de estar em total dependência da causa final, embora a principal virtude em qualquer desses discursos seja a clareza - vale dizer, a mais próxima semelhança entre a coisa pensada e sua representação pela linguagem. Porém, uma vez que, na poesia e na retórica, os discursos hão de ser carregados de afetos e de caracteres, relativos às grandezas, indignidades, bondades e fealdades das coisas, e não visam à verdade, o mais importante é que essas qualidades das coisas sejam transportadas ao pensamento pelas próprias figuras de linguagem. A léxis poética e a retórica, portanto, hão de ser meio de representação dos acidentes que envolvem as substâncias, mas sem recurso ao espetacular, às entonações, aos gestos etc. - sem se esquivarem à lógica, em suma.

Isso torna-se mais claro no final do cap. xxIv da Poética, quando, após defender que a poesia nada deve ao "irracional", que os absurdos que nela constar devem parecer razoáveis, e que isso se efetua ocultando-os sob "primores de beleza", Aristóteles conclui que se deve, sim, aplicar esforços no embelezamento da linguagem, mas "tãosomente nas partes desprovidas de ação, e que não se destacam nem pelo caráter nem pelo pensamento", pois, diz ele, "uma elocução demasiado brilhante ofusca caracteres e pensamentos". Ora, ação, caracteres e pensamentos, afirmara no cap. VI, são as partes principais da fábula poética, constitutivas do próprio mythos; logo, fazer depender o ornato elocutivo do ocultamento da fábula é precisamente dizer que ele só encontra lugar extra-fábula, confirmando, por um lado, a união entre elocução, melopéia e encenação, e, por outro, apartando-as o mais possível da arte do poeta (relegadas que são tais partes à arte dos atores): seu pertencimento, portanto, é remetido menos à mímese do que à mímica. Delimitando na poesia e na oratória, assim, como elocução subordinada à fábula e à causa, respectivamente, os modos excessivos e desviantes de as palavras significarem, pelas figuras de linguagem, Aristóteles, com um mesmo gesto, devolve-os ao âmbito da significação (um âmbito portanto reduzido, decorativo, afetivo) e circunscreve o campo daqueles modos que, de todo incapazes de se conformar à arte, são definitivamente destituídos de significação: sejam os enigmas, sejam os que decorrem da engenhosa diç̧ão do orador (e do ator), da melopéia, da cenografia.

Desde sempre, porém, com as homonímias, as anfibologias, as sínteses, as diéreses, a prosódia e a dicção, a vocalidade infixa da palavra escapa do quadro em que a metafísica aristotélica a deposita, como sobre-sentido ou não-sentido. São essas as seis categorias pelas quais, segundo os Elencos sofísticos, se reconhecem as falácias, ou seja, os modos pelos quais "não manifestamos a mesma coisa mediante os mesmos 
nomes e os mesmos enunciados" (Iv, 165b 28-9). Se, nos Elencos, Aristóteles ensina a identificar como as palavras se perdem em vozes falsamente significativas, para que, assim ensinado, alguém (i. e., aquele que filosofa) possa reconduzi-las à sua própria significação, na Retórica e na Poética ele se limita a aconselhar parcimônia no uso dos equívocos, subordinando-os ao objetivo de, desviando-se um pouco da linguagem corrente, ornarem o discurso - uma vez admitido que, aí, "as palavras são imitações" e que a voz é de todos os órgãos o mais próprio à imitação (Retórica, III, 1, 1404a 21). Quer dizer, na poesia e na retórica, que não visam a apreensão da verdade, mas tão só de um possível, os equívocos são adequados desde que reflitam o tom afetivo ou característico que se quer fornecer às coisas, verossimilmente. Portanto, só na exterioridade da metafísica, o corpo verbal (incorpóreo som, letra visível) das palavras pode se tornar significante das exteriores semelhanças entre os corpos: porque elas tratam dos acidentes da matéria, submetidas às ações e paixões da ordem das ocasiões e dos lugares.

Todavia, apesar disso, de serem desprovidas de relações causais na ordem das coisas, as palavras imitativas, para Aristóteles, são naturais e prazerosas e produtoras de verossímil - vale dizer, inevitáveis, como inevitável é a matéria. Daí que o rol classificatório de metáforas, bem como o das figuras de linguagem e de pensamento, e ainda o estudo dos ritmos do verso e dos períodos da frase, aproximando a retórica da poética, contêm-nas nos limites legitimados da verossimilhança, de modo que a variação de sentidos imposta pela instabilidade das palavras pronunciadas, por si mesmas ou em conjunto, não ultraje a arte constituída da elocução, nem dos afetos calculados para a eficiente expressão da causa - sem descambar, conseqüentemente, para um prazer hospedado nos próprios sons: para um sentido alheio àquele das coisas a que é suposto referirem-se. Um verossímil é ainda uma apreensão possível das coisas, em sua materialidade circunstancial, que obedece aos princípios da lógica: sobretudo, o da não-contradição.

Por isso, o problema aristotélico parece que não está tanto em que uma palavra signifique várias coisas. Para isso há as interpretações que dizem os modos legítimos das palavras significarem: por exemplo, em que sentido metafórico uso a palavra homem, se em gênero, se em espécie, se em indivíduo. O problema reside, sim, em que uma palavra possa ter vários sentidos, independentes uns dos outros, e que estes possam se encadear sintaticamente, pelos sons ou pelas imagens, suscitando afetos que ignorem a lógica. Os exemplos que Aristóteles dá de um estilo "poético" de Górgias (Retórica, III, 1, 1404a 26 e III, 7, 1408b 20), ou ainda, sua censura de que Górgias faz "metáforas frias e de muito longe" (Retórica, III, 3, 1405b 38 e 1406b 9 e 15-19) vai diretamente neste sentido. [O exemplo de um estilo "demasiadamente poético e não persuasivo de Górgias" é aquele segundo o qual Górgias teria dito a uma andorinha que lhe lançara um excremento: "Que vergonha, ó Filomela"; quer dizer: se filomela é 'andorinha' e é o 'nome de uma 
jovem', ao dizer que é vergonhoso filomela lançar um excremento, Górgias está adjetivando como obsceno o ato de uma mulher, não de um pássaro, ou efetuando qualquer outra relação, embora esta seja impossível, ou inverossímil, ou imoral na physis.]

Ao contrário da elevada poesia, o sofista faz com que a sonoridade não se fixe em uma coisa, mas fá-la transitar entre todas as coisas possíveis e produzir sentidos jocosos, a maior parte das vezes - que suscitam sorrisos, deleites e prazeres vãos. Nem sempre há um conhecimento, como quer Aristóteles com a transposição legítima operada pela metáfora, na retórica e na poesia: pelo contrário, pode haver conhecimento nenhum, ou um falso conhecimento, ou ainda um conhecimento de que as coisas se auto-contradizem. É isso que Aristóteles não pode admitir, para não admitir que a poesia e a retórica se oponham à filosofia e que sejam excluídas dos campos de saber da sua pólis.

Consideram-se as figuras gorgianas, isto é, a aliteração, a paronomásia, os isocólons e a rima como infrações ao sentido porque nelas haveria proximidade de sons sem que houvesse semelhanças de ordem lógica. No entanto, a infração reside mais em que a conivência das significações fica como que autentificada pelo eco das sonoridades, os significados deslizando no sentido. A contraposição dos membros ecoa as similitudes, o sentido nunca se fixa em uma única coisa. Nisso, aderem às formas predominantemente orais da poesia: a versificação, o número silábico, a acentuação, o ritmo, a rima. Todos estes são procedimentos que, em vez de tentar sujeitar ou ultrapassar a materialidade significante da palavra, exploram-na.

Por isso Aristóteles diz que a quem usa as palavras assim não se pode aplicar os princípios de contradição e identidade lógicas, mas apenas se pode fazer calar: pois não se pode refutar o que há nos sons da voz e das palavras. E Platão, no Górgias, que não se pode traduzir uma epidéixis sofística, nem sequer resumi-la, mas apenas indefinidamente repeti-la, palavra por palavra - o que enlouquece os tradutores, entre outras coisas. É uma forma espúria de fazer com que dizer e pensar (léxis e logos) sejam uma mesma coisa.

Nuclear aqui é o capítulo xxv dos chamados "problemas críticos” da Poética, em que, não por coincidência, aparecem as mesmas categorias do capítulo IV dos Elencos sofísticos, só que na Poética desprovidas de censura filosófica e aduzidas, pelo contrário, como procedimentos inerentes à poesia. Aristóteles busca mostrar que, mediante uma adequada interpretação da elocução poética, descobre-se quando suas sentenças não são nem impossíveis, nem irracionais, nem imorais, nem contraditórias, nem contrárias à arte (Poética, XXv, 1461b 21-23) - constituindo então o campo daquelas que o seriam. 
Nesse capítulo, depois de se referir aos modos como o poeta pode se livrar da censura de imitar impossíveis, falsidades, impropriedades e erros, Aristóteles aborda os contraditórios, dizendo: "Quanto às contradições, há que considerar em que sentido foram ditas, como nos argumentos refutativos da dialética, e ver se se diz o mesmo, em relação ao mesmo e no mesmo sentido, de sorte que o poeta contradiga o que ele mesmo diz ou o que pode supor um homem sensato" (idem, XXv, 1461b 14-17, grifos meus). E, precisamente "como nos argumentos refutativos da dialética", elencados nos Elencos ou Refutações sofísticas, Aristóteles expende os modos pelos quais alguém não diz o mesmo, em relação ao mesmo e no mesmo sentido.

Segundo a ordem em que aparecem nos Elencos, o primeiro modo é a homonímia, dada por Aristóteles na Retórica como o procedimento por excelência dos sofistas (III, 2,1404b 37-39) e definida nos Elencos como quando o nome, na acepção própria, tem mais de uma significação. Na poesia, o mesmo procedimento é denominado estranheza, isto é, quando as palavras têm outro sentido próprio além daquele corriqueiro, o qual sentido, por não ser compreendido, faz com que se interprete uma passagem poética como contraditória. Um dos exemplos de Aristóteles é, na Ilíada (I, 50), o uso da palavra oureus, significando 'sentinela', quando freqüentemente significa 'mulo' ou 'macho'.

O segundo modo, estreitamente vinculado à homonímia, é quando a estrutura sintática de uma frase permite mais de um sentido próprio, tornando-se desse modo ambígua. Apesar de o português ter uma estrutura sintática muito mais rígida que o grego, o exemplo dado por Aristóteles pode ser vertido ao português, que, numa frase de ordem normal sujeito-verbo-objeto, permite a inversão da posição do objeto para a de sujeito; assim, uma frase como "eles conhecem as letras" pode ser dita "as letras conhecem eles", o que inverte o sentido da oração e a relação sujeito-objeto.

O terceiro e o quarto modos são, respectivamente, a diérese e seu oposto, a síntese, que ocorrem quando separam-se com uma pausa termos que deveriam estar ligados, ou, o contrário, unem-se termos que deveriam ser separados com uma pausa. O exemplo dado na Poética é o de uma sentença de Empédocles, que poderia ser traduzida mais ou menos assim: "agora se tornaram mortais as coisas que antes eram imortais, e as puras misturadas"; deslocando o lugar da vírgula, a sentença pode ser entendida como: "agora se tornaram mortais as coisas que antes eram imortais e puras, misturadas".

O quinto modo é a prosódia ou acentuação, cujos exemplos são os mesmos tanto nos Elencos como na Poética. Em ambos trata-se de passagens de Homero, nas quais a acentuação diversa de uma palavra torna-a outra, afetando o sentido de toda uma oração. 
O sexto e útimo modo é a forma da expressão ou o costume pelo qual modos de atividade são expressos por termos cuja terminação é própria da passividade, ou as de qualidade por termos de quantidade, ou de masculino por feminino etc. "Avermelhar", por exemplo, é uma palavra que se assemelha pela forma a "cortar" ou "edificar" e, no entanto, designa uma qualidade ou estado, enquanto as outras designam uma ação.

Com base nessas afecções da linguagem, que levam o ouvinte a se ater aos sons e aos significantes das palavras, para Aristóteles, ${ }^{4}$ os sofistas produziriam pensamentos errados, ao passo que os poetas produziriam pensamentos verossímeis.

Há somente uma figura de linguagem que, dada como própria da léxis poética, não comparece nos Elencos. Trata-se da metáfora (que, para Aristóteles, inclui as que chamamos metonímias e sinédoques), e que aparece como uma figura de substituição por analogia. Dissemos no início que, para Aristóteles, a palavra é signo, símbolo dos movimentos da alma e, essa, é afetada pelas coisas. O que se passa na alma, passa nas palavras - é uma transitividade, das coisas para a alma e destas para as palavras. A metáfora é procedimento elocutivo privilegiado tanto na Poética como na Retórica porque permite à alma fazer imagem daquelas coisas que não se deixam ver pelos sentidos, como numa pintura, tornando-as claras e como atuantes. Ora, sabemos a ênfase que dá Aristóteles, tanto na retórica como na metafísica, à demonstração ou apodéixis: a partir do que é mostrado, demonstrar. Mostrar o que é, a causa e o porquê. E mostrar com nomes próprios, definições claras, silogismos concludentes, metáforas esclarecedoras. As metáforas, pois, são figuras pertinentes à elocução poética e retórica por comportarem conhecimento, deslocando por analogia as coisas em relação a seus gêneros e espécies, e fazendo ver o semelhante. Esta é uma das razões por que Aristóteles insiste em que elas não devem ser trazidas de longe, como faz Górgias. É principalmente neste comportar conhecimento que as metáforas causam também prazer, já que instruem sobre as coisas - e, segundo o princípio inaugural da Metafísica, todo homem, por natureza, deseja saber. Enfim, aquele outro prazer obtido pelas semelhanças superficiais entre sílabas, acentos e pausas não corresponde a qualquer logos: é casual.

Em contraposição à apodéixis, a epidéixis é o modo de exposição privilegiado pelos sofistas, distinguindo-se daquela por ser uma arte de mostrar diante, exibindo e valorizando no discurso o que se mostra: como belo ou feio, honroso ou vergonhoso, presencialmente. Como num espetáculo, numa atuação, numa encenação. Na Retórica, Aristóteles inclui os discursos epidíticos como um dos três gêneros retóricos, definindo-o como aquele que tem por alvo mostrar que uma coisa é bela ou feia, quer dizer, virtuosa ou vergonhosa. Nisso, o orador do discurso epidítico não se afastaria dos demais procedimentos da demonstração, considerada em termos lógicos, embora com 
ênfase nos tópicos de amplificação: isto é, do seu ofício é próprio não só demonstrar ser algo justo ou injusto, útil ou nocivo e, no caso, virtuoso ou vergonhoso, mas sobretudo demonstrar ser algo mais ou menos virtuoso, vergonhoso etc. Como a retórica pressupõe que os discursos são realizados porque há opiniões diversas, em que a demonstração de coisas sujeitas às circunstâncias de tempo, espaço e pessoas não pode ser a da verdade, mas apenas a das maiores possibilidades de se assemelhar ao verdadeiro, $\mathrm{o}$ discurso epidítico, tendo a amplificação por seu argumento mais adequado, aparece assim como o discurso mais retórico entre os três gêneros. ${ }^{5}$ Todavia, na Retórica, o discurso epidítico esbarra numa aparente contradição, que é a de não propor uma ação ou uma práxis que seja fim do discurso. Os intérpretes se esmeram em definir qual o papel do auditório num discurso que não exige do ouvinte nenhuma ação propriamente dita, relativamente ao assunto tratado, a não ser a ação de contemplar o orador. Pois, diz Aristóteles,

as espécies de retórica são três em número, uma vez que outras tantas são as classes de ouvintes dos discursos. Com efeito, o discurso comporta o orador, o assunto de que se fala e o ouvinte; e o fim do discurso refere-se ao ouvinte. Ora, é necessário que o ouvinte seja ou espectador ou juiz, e que um juiz se pronuncie sobre o passado ou sobre o futuro. $\mathrm{O}$ que se pronuncia sobre o futuro é, por exemplo, um membro de uma assembléia; o que se pronuncia sobre o passado é o juiz; o espectador, por seu turno, pronuncia-se sobre o talento [dynamis] do orador (Retórica, I, 3, 1358a 36-1358b 6).

Isto faria dos discursos epidíticos o lugar por excelência da exibição do orador, independentemente do assunto tratado: exibição inútil e aparatosa, como a de oradores sofistas. $\mathrm{O}$ belo e o feio, o virtuoso e o vicioso, como fins para aqueles que elogiam ou censuram, respectivamente, permaneceriam como alvos de contemplação e, portanto, de puro deleite discursivo. Apesar disso encontramos claramente na Ética o lugar de necessidade prática, ativa, que Aristóteles atribui aos discursos chamados epidíticos. Aí diz ele que:

admitimos como princípio que a virtude, no que se refere ao prazer e ao sofrimento, é a capacidade de realizar as ações mais belas, sendo o vício a disposição contrária ... Há três objetos de escolha e de repulsa, que são respectivamente condicionadas pelo nobre, pelo útil e pelo agradável, como escolha, e pelo que é injusto, nocivo ou triste, como repulsa; sobre todas essas coisas o homem bom acerta, enquanto o vicioso erra, princi- 
palmente no que se refere ao prazer. Com efeito, o prazer é comum a todos nossos atos deliberados, porque o bem e o útil nos parece agradável. ... Por conseguinte, regulamos todas as nossas ações pelo prazer e pela dor, uns mais e outros menos. É, pois, inevitável que nosso estudo tenha em vista o prazer e a dor, pois tem grande importância para nossas ações saber se nos deleitamos ou sofremos para nosso bem ou para mal.

Quer dizer, os discursos epidíticos assumem um lugar cimeiro entre os discursos porque, ao demonstrar de certa coisa sua beleza, virtude e prazer (ou seus contrários), ditam a regra para todas as ações que se deliberam, subordinando a si tanto a justiça como a utilidade das ações. No fim, é o prazer (ou o sofrimento) que se espera de algo que dirige a escolha das ações. Por isso, a importância dos discursos que conseguem mostrar como prazerosas e belas e virtuosas, igualmente, as ações de um homem porque belo, virtuoso; e porque virtuoso, feliz. A concordância dessas qualidades é o que, na Política, garante que o bem comum não se opõe ao bem particular, fundamentando as práticas sociais. (Seria preciso ainda mostrar que a contemplação, na ética e na política aristotélicas, não se opõe à ação, aparecendo como a atividade mais virtuosa da alma. Todavia, não é este o momento para desenvolver tal assunto.)

Então, sabido que a demonstração da virtude ou vício de uma ação reverte para o orador, caracterizando-o como virtuoso ou vicioso, o que, por sua vez, dota de confiança o discurso para o auditório, é fundamental para Aristóteles que seja pela apodéixis, ou seja, pela demonstração lógica, que num discurso apareçam a justiça, a utilidade e a virtude de uma ação, a qual demonstração sirva por conseguinte de prova do caráter justo, benévolo e virtuoso do orador. E nunca pela mímica, pela entonação, pela pronunciação - por uma actio exibida.

Enfim, encontramos nos escritos filosóficos de Aristóteles uma total conivência entre suas concepções metafísicas (que têm por axioma os princípios da não-contradição e da identidade); o lugar circunscrito da linguagem como meio de transmissão dos pensamentos (que se distinguem entre os verdadeiros, os possíveis e os falsos); e a relação de tais pensamentos com a ordenação da vida política (pública e particular).É uma tal concordância entre o físico e o metafísico que os escritos de Górgias rejeitam, por via precisamente de discursos epidíticos, estruturados numa léxis gorgiana, no momento em que desconhecem os pressupostos aristotélicos, começando pelos metafísicos, até os dialéticos, os poéticos e os políticos.

O exórdio do Elogio de Helena é exemplar nesse sentido. Górgias principia defendendo, de modo algum paradoxalmente, que a ordem ou ordenamento de uma cidade está no valor de seus cidadãos, do mesmo modo como a de um corpo está em 
sua beleza, a de uma alma em sua sabedoria, a de uma ação em sua virtude e a de um discurso em sua verdade; o que não for isso será a desordem ou o caos. Por essa razão, diz ele, tem por propósito fazer um discurso sobre Helena em que elogie o que for elogiável e censure o que for indigno. Deste modo, pretende:

ao dar uma lógica ao discurso, sustar a acusação contra aquela da qual se ouve tanto mal, demonstrar que seus difamadores se enganam e mostrar a verdade, fazendo cessar a ignorância (Elogio de Helena, 11.2).

Desse exórdio podemos extrair dois pressupostos: primeiro, que Górgias não reconhece uma virtude única para coisas tão diversas como pólis, soma, psiquê, práxis e logos, atribuindo a cada uma sua excelência própria, quais sejam, respectivamente, euandria, kálos, sophía, aretê e aletheia. O segundo que, ao dar uma lógica ao logos, o orador ao mesmo tempo atribui justiça ao que é justo, afasta os enganos e diz a verdade. São pressupostos éticos que não poderiam deixar de ser assinados pela Retórica aristotélica, que, à diferença do Górgias platônico, tanto admite na política a necessidade de atribuir a cada espécie de ser excelências diversas próprias, como admite a caracterização ética do orador por um discurso que se mostra regido por uma adequação entre elogio, justiça e verdade. As discordâncias entre as concepções de linguagem de Aristóteles e de Górgias são outras.

O elogio que Górgias se propõe a fazer de Helena passa rapidamente pelos topoi de ascendência e beleza, omitindo declaradamente a narração das ações conhecidas pelo auditório que levaram ao seu desembarque em Tróia, para averiguar as razões possíveis para que ela tenha abandonado o esposo grego. São quatro as razões dadas por Górgias: o Destino, a Força, o Discurso ou o Amor. Os dois primeiros argumentos são facilmente anulados como causa de ignomínia para Helena: valendo-se dos lugares comuns de inferioridade e superioridade, Górgias prova que se Helena deixou a pátria por causa do Destino, só pode ser considerada uma vítima dos deuses; e se foi conduzida pela força de Páris, sofreu um ultraje - em ambos os casos Helena aparece como submetida a um poder superior, frente aos quais não poderia ser contrária. Mais difícil parece derrubar os argumentos de que Helena se deixou persuadir pelo discurso de Páris ou de que se enamorou por ele, pois ambas as causas - a persuasão e o amor pressupõem um consentimento da parte do que é afetado e do que é persuadido, tornando-a responsável por ter abandonado a virtude principal de uma mulher, qual seja, guardar fidelidade ao esposo em seu lar.

No argumento relativo à persuasão pelo discurso encontramos a cisão entre o pensamento de Górgias e o de Aristóteles. Nesse Elogio, o principal argumento para 
defender a incapacidade de Helena de ter resistido à persuasão, é aquele segundo o qual o Discurso, como um poder soberano, tem a mesma disposição relativamente à alma que os fármacos relativamente aos corpos. Diz Górgias: "o Discurso tanto pode deter o medo, como afastar a dor, provocar a alegria e intensificar a compaixão" (Elogio de Helena, 11.8), exemplificando com o discurso poético:

A poesia toda, considero-a e defino-a como um discurso com metro. Sobrevém àqueles que a escutam o tremor de quem transe de medo, a piedade de quem abunda em lágrimas, a tristeza de quem sofre a dor, e, diante de felicidades e de reveses que sucedem a ações e corpos estranhos, a alma prova, por intermédio dos discursos, uma paixão que lhe é própria (Elogio de Helena, 11.9).

Por isso, tal como o corpo obedece a fármacos independentemente da razão, a alma é afetada pelos discursos, independentemente da mesma razão. Górgias reforça sua argumentação sustentando que outros discursos que não os poéticos - o dos físicos, o dos dialéticos e o dos filósosfos - também se valem da persuasão ao constranger a alma a consentir nas coisas que são ditas e nas que são feitas. Todos eles debatem opiniões, que é a guia incerta e inconstante de todos, já que ninguém pode ter, acerca de tudo, nem previsão do futuro e do presente, nem memória do passado: os astrônomos disputam as dimensões dos astros, que nunca serão medidos; os dialéticos encantam as multidões, ao "redigirem discursos com arte, sem que a verdade seja pronunciada"; os filósofos, finalmente, alteram com discuros velozes a confiança da opinião.

Em todos esses exemplos, o que Górgias diz é que não são as coisas que fazem a alma sofrer, mas sim o que o logos (a razão e o discurso, a racionalidade da discursividade) diz delas. Se alguém vê um homem com armas e isso lhe significa um inimigo, ele amedronta-se e foge, ou se encoraja e luta; se lhe significa que é uma comédia, ele ri. E assim por diante. Basta ter ouvidos para ouvir palavras, e basta ter olhos para ver coisas amáveis e temíveis, pois há sempre aparências e sons que enganam. É no interior deste engano (apatê), cujo consentimento é inevitável e irresponsável, que o verossímil se instala. E isso é ser homem: é não ser insensível: é ter corpo e alma: no qual se dê catarses. Segundo Plutarco (ao falar da tragédia), para Górgias

“aquele que ilude é mais justo do que o que não ilude, e aquele que é iludido é mais sábio do que o que não é iludido". Com efeito, quem ilude é mais justo porque faz o que promete; quem é iludido é mais sábio pois quem se deixa impressionar pelo prazer das palavras não é insensível (De gloria Atheniensium, 348c 5). 
No Sobre o não-ser, temos posta esta mesma relação entre o logos e as coisas. Aí Górgias diz que "não é o discurso que indica o exterior, mas o exterior que vem revelar o discurso" (\$85), como se o movimento fosse inverso àquele preconizado por Aristóteles. Ou seja, diz-se uma palavra, ela configura o pensamento, a coisa significada passa a ter tais e quais qualidades para aquele que a pensa, porque a pensa com afetos e caracteres. Se se pensar com tais argumentos, com as palavras postas dessa maneira, Helena será inocente; se com outros, e de outra maneira, culpada. Sem que haja uma verdade física ou metafísica exterior ao logos.

Evidentemente, Górgias é o paradigma, mas não é o um caso isolado, desde que em toda a sofística encontramos escritos que, ao tomar a léxis como logos, exigem que este, para ser lógico, isto é, para ser discurso, conforme-se às leis da léxis, uma vez que a verdade possível alça-se sobre o verossímil - não o contrário. Esse é o caso - para manter a origem épica do logos grego - do undécimo discurso de Díon Crisóstomo de Prusa, "Aos ilienses, em que demonstra que Tróia não foi capturada". Tomando por base as contradições presentes na Ilíada, e interceptando-as com o que se lê na Odisséia, nas tragédias e nas histórias, esse discurso pretende mostrar que "em nada Homero falou a verdade", mas tudo escreveu a fim de glorificar os gregos - não esquecendo nós que os discursos de Díon foram escritos em grego sob o domínio romano de Domiciano (de quem recebeu exílio), Nerva e Trajano (de quem favores). Sabido que ninguém considera os sucessos relatados na Ilíada verdadeiros, Díon opera contudo com o pressuposto de que o verossímil homérico é mais constrangedor do que a verdade, de modo a provar que Helena não poderia ter sido casada com Menelau (mas que Páris era seu legítimo esposo), que Heitor não poderia ter sido morto por Aquiles (mas vice-versa), e que Tróia não poderia ter sido capturada (mas Grécia a derrotada). Ou seja, afirma que os episódios narrados não existiram; ou, se existiram, não sucederam assim; ou, os que sucederam, têm um sentido diverso. No final, Díon defende-se, no mesmo golpe, da suspeita de estar ultrajando a Grécia com a verdade do que diz, que é mais honrosa - sempre - que a ilusão e com a explicitação de que a verossimilhança poética da Ilíada não é arranhada pela lógica de discurso algum:

Talvez alguém desinformado possa dizer, "não é certo você depreciar os gregos deste modo". Bem ... a verdade é merecedora de um preço elevado. E além disso, tivesse eu sabido que minhas palavras persuadiriam alguém, talvez me decidira a não falar coisa alguma. Mas, contudo, mantenho que libertei os gregos de maiores e mais tristes opróbrios. Que um homem falhe em capturar uma cidade não é nada inusual, nem é ... opróbrio. Mas o mais bravo dos gregos [Aquiles] ser morto 
pelo mais covarde entre os inimigos, [Páris] isso com efeito é uma grande vergonha ... Além disso, quando Astianáx, o filho de um nobre guerreiro, é tão brutalmente morto sendo atirado das muralhas da cidade e isso com o consentimento unânime do exército e dos reis; quando a virgem Polixena é sacrificada sobre uma tumba e tais libações são feitas pelo filho de uma deusa; quando Cassandra, uma virgem consagrada e sacerdotisa de Apolo, é ultrajada no santuário de Atena, abraçada à estátua da deusa, e isto é feito não por alguém obscuro ou indigno, mas por um dos mais proeminentes líderes; quando Príamo, o rei da Ásia, em velhice extrema, é ferido atrás do altar de Zeus, de quem era descendente, e por isso é escarnecido, e não é alguém desconhecido que perpetra esse feito, mas o próprio filho de Aquiles ...; quando Hécuba, a tristemente abatida mãe de tantos filhos, é dada a Odisseu para sua vergonha e, sob o peso de suas misérias, é transformada em um cão uma idéia completamente ridícula; e quando o senhor dos gregos toma como noiva uma donzela consagrada a Apolo, com quem ninguém ousaria casar por medo do deus - um ato pelo qual é levado a encontrar o destino merecido - quão melhor para os gregos nunca terem cometido esses excessos que terem capturado Tróia! (Undécimo discurso, em que demonstra que Tróia não foi capturada, §150-4).

Enfim, o verossímil é mais persuasivo do que o verdadeiro, "porque todos os homens aprendem com dificuldade e facilmente se iludem" (idem, $\$ 1$, grifo meu) e porque "a verdade é amarga e desprazerosa, enquanto a falsidade é doce e agradável" (ibidem). A ilusão, uma ilusão consentida, ou opinião, é o que faz os homens agirem, seja para construir seu futuro, seja seu glorioso passado. E esse é exatamente o último argumento que Górgias traz para defender Helena, caso se considere que ela sucumbiu ao erro devido ao Amor.

O sofista procura demonstrar que a alma é afetada pela vista, da mesma maneira que pelos discursos, desde que as coisas vistas têm, não a natureza que pretendemos que tenham ou a que lhes poderia pertencer, mas aquela que lhes cabe pelas circunstâncias; em todos os homens, a razão, por sua vez, se perde e se perturba pelas impressões que a vista deixa na alma. Assim, algumas imagens aparecem como terríveis, alterando a alma e obrigando as pessoas a fugir, como se de um perigo presente se tratasse, enquanto outras atraem o desejo e o amor, como as pinturas e esculturas perfeitas, cuja vista do belo é discernida conformemente à lei, e a do bem se produz conformemente à justiça. Portanto, se Helena se apaixonou pela visão de Páris, julgando-a imagem do belo e do bem, pode ter sido ou uma doença humana ou uma ignorância da alma, mas não uma falta, pela qual possa ser considerada injusta ou indigna. 
Desse modo Górgias chega ao fim do Elogio de Helena. Segundo Barbara Cassin, esse discurso foi pronunciado numa ocasião em que enviado a Atenas, Górgias, num dia, persuadiu a ágora de que Helena era a mais culpável das mulheres e, no dia seguinte, que era a própria inocência. ( $\mathrm{O}$ pretenso discurso de acusação não sobreviveu.) Então diz a autora:

Essa história, nem verdadeira nem falsa, é plena de sentido: o nome de Helena pode servir de emblema para uma posição sofística do discurso por contraste com uma posição filosófica. ... Górgias faz entender até que ponto a inocência de Helena não é nada além que sua culpabilidade. ... De qualquer lado que se veja, Helena é inocente de ter este corpo que a faz culpável (L'effet sophistique, 1995, p. 76-7).

De um lado um modelo físico de mundo em que se trata de determinar seus princípios imutáveis e demonstrá-lo, como Aristóteles procura fazer, fazendo deles garantia metafísica sobre todas as esferas humanas; de outro, um modelo político, ético de mundo, em que se trata de plasmar, momento a momento, discurso a discurso, os valores comuns que constituem a opinião e a ação comuns. Ver o sol pequeno, ver um teatro, ouvir uma discussão de filósofos nada tem a ver com o mundo dos fenômenos físicos, mas com o sentido que lhes é fornecido e com o qual o homem opera no mundo. Quando se atinge o âmbito do sentido, não há uma mesma coisa, que dirá uma mesma virtude: o sol do agricultor sequer é o dos astrônomos. E não há uma palavra para uma coisa, porque cada palavra é uma coisa. Os sofistas recusam-se a definir, passando de uma coisa a outra, de uma palavra a outra, porque, estando contido na léxis, o logos tem a sua realidade de homonímias, de antíteses, de prosódias, de reciprocidades.

O epidítico, como discurso sofístico - ou seja, juntamente poético e retórico não usa as palavras como símbolos de uma outra coisa e não persuade a coisa alguma, pois visa a divertir, agradar, dar prazer e dissipar a dor; considera as palavras coisas pequeninas que fazem ações imensas. Por isso, atém-se aos significantes, descola-se das coisas externas e se impõe como coisa também. Até que as coisas se mostrem como o discurso diz que elas são, para o ouvinte e para o orador. Concebidas dessa maneira, as palavras não são um instrumento do conhecimento, mas um phármakon: que injeta ou extirpa pensamentos, afetos, opiniões. Enquanto, para Aristóteles, fala-se para significar, fala-se de, para dizer uma coisa; para Górgias fala-se simplesmente de um para outro, sobre coisas que nunca têm uma substância única, são opináveis, e pelo puro prazer de falar. ${ }^{6}$ É assim que termina o Elogio: 
Com esse discurso, fiz desaparecer a ignomínia que pesava sobre uma mulher, mantive-me na lei que fixei no início, tentei dissipar a injustiça da acusação e a ignorância da opinião, quis escrever este discurso como um elogio para Helena e um divertimento para mim.

Isto é, Górgias não pretende a verdade, com a qual não opera, mas, pela lógica que fornece ao discurso, visa a afastar a injustiça e a ignorância sobre uma personagem de ficção, o que é nada mais nem menos do que um prazer para si. Sua anti-épica finalidade é a afirmação de que o mundo das aparências é fator coercivo das ações, tanto quanto os discursos, cujas formas corporais dispõem de qualidades, as quais impõem os afetos que fazem a razão variar. A verdade é ocasional. E o verossímil - ou simplesmente o símil, o semelhante - rege as relações entre os pensamentos dos homens e as coisas. A poesia, que é discurso com metro, e a pintura, que é pura imagem sem corpo, qualidade sem substância, são assim semelhantes aos discursos retóricos dos sofistas, que se exibem como formas destituídas de verdade, mas cheias de prazer ou de terror. Entendemos assim um dos motivos por que Platão, no Sofista, em nome da ontologia, repudia com um só golpe a sofística, a poesia, a retórica e a pintura. De um discurso epidítico tal como os compostos por Górgias, por Díon e outros o ouvinte sai instruído e prazeroso, não sobre a physis, o universal, o necessário, mas sobre a imitação, os enganos, as aparências. Por isso aquela desconfiança de Aristóteles de que Górgias é por demais poeta, não cuidando da verdade para cuidar das palavras: transitando da léxis para o logos como se fossem o mesmo. Mas se a poesia não for só o discurso com metro, como pretende Górgias, mas, pelo contrário, o metro for mero acessório de um discurso que mimetiza o universal, as semelhanças entre os discursos sofísticos, a pintura e a poesia serão também meras aparências, destituídas de substância na ordem das relações de gênero. A diferença real entre os sofistas e os poetas, para Aristóteles, é que os sofistas dizem coisas sem relação ou em contraposição à physis na própria physis - ocupando o mesmo espaço que o filósofo e o orador, esquecendo a sensatez, que os poetas têm, os quais só operam com a léxis como excesso, ornamento ao logos. Já os sofistas, poderíamos dizer, operam com o logos como um ornamento, um excesso em relação à léxis. Até isso seria possível na poesia, "mas o que distingue a sofística dos demais usos da palavra, do logos, não é a potência, o método: e sim a escolha" - escolha de enganar, diz Aristóteles (Retórica I, 1, 1355b 19). ${ }^{7} \mathrm{Na}$ sofística está fundida a retórica e a poesia versus a filosofia, as quais Aristóteles vai a custo separar. A retórica está próxima da política e da dialética, por um lado; e a poesia está próxima da filosofia, por outro. A sofística não tem lugar como saber, nem portanto como prazer. 
Em suma, a diferença entre o poeta e o sofista, para Aristóteles, não está nem nas figuras de linguagem e de expressão, nem em promover o falso, nem em ir contra a ética e a política: mas está no seu fim: o fim do sofista é saber dizer que o falso pode ser verdadeiro, que o não-ser pode ser: esta sua escolha e o seu engano. $O$ poeta não diz que o falso é verdadeiro, porque diz que apenas imita o verdadeiro, procurando por falsidades aparentes compor uma verdade possível; o poeta diz claramente, por meio de metáforas, que aquele falso que se parece verdadeiro, apenas se parece: é verossímil. Verdadeira ele diz que é apenas sua imitação. E imitar não é enganar: é ensinar e dar prazer para que os homens saiam melhorados, com suas falsidades necessárias, purgados. $\mathrm{O}$ contraditório pode ser incluído em vista desse fim, que dá toda a dignidade à poesia em relação ao homem comum, sensato, político, lógico, com caracteres e afetos, e, no mesmo golpe, constitui o âmbito do insensato, do incomum, do apolítico e alógico, inumano sofista. ${ }^{8}$

\section{Notas}

* Professora Doutora do Departamento de Teoria Literária do Instituto de Estudos da Linguagem da Unicamp.

1 Veja-se os Segundos analíticos, II, 10, 93b 35: "Um discurso é um de duas maneiras: em virtude de um nexo simples, como a Ilíada, ou porque exprime um só predicado de um só sujeito, que não por acidente", e Metafísica, 1045a 12-14.

2 Cf., por exemplo, o interessante estudo de J. Lichtenstein, A cor eloqüente.

3 "Homero foi também o grande mestre dos demais poetas em dizer como se deve o que é falso - refiro-me ao paralogismo", Poética, xxiv, 1460a 19.

4 A interessante questão, levantada por Louis-André Dorion, tradutor francês dos Elencos sofísticos, de que Aristóteles não se insurge contra os primeiros sofistas (Protágoras, Górgias, etc.) mas mais diretamente aos megarenses, não vem ao caso aqui. Os seis procedimentos lexicais identificados por Aristóteles como próprios das falácias sofísticas são reconhecíveis nos discursos de Górgias, independentemente de a obra visar ou não a esse sofista.

5 "A amplificação enquadra-se logicamente nas formas de elogio, pois consiste em superioridade e a superioridade é uma das coisas belas ... Entre as espécies comuns a todos os discursos, a amplificação é, em geral, a mais apropriada aos epidíticos; pois estes tomam em consideração as ações por todos aceites, de sorte que apenas resta revesti-las de grandeza e de beleza." Retórica, I, 9, 1368a 23-9.

6 Cf. Aristóteles, Metafísica IV, 1009a 16-22: "Se todas as opiniões e impressões são verdadeiras, todas as coisas serão necessariamente verdadeiras e falsas ao mesmo tempo e, se é assim, necessariamente serão verdadeiras todas as opiniões ... Mas a maneira de 
enfrentar-se com o adversário não é a mesma com relação a todos, pois uns necessitam de persuasão e outros, de constrangimento. Quantos chegaram a pensar assim a partir da dúvida, sua ignorância é facilmente curável (pois o enfrentamento com eles não é da ordem das palavras, senão da ordem do pensamento). Mas a quantos falam por falar não se lhes pode curar mais que refutando o expressado na voz e nas palavras."

7 Ver também Metafísica IV, 1004b17-26: “os dialéticos e os sofistas revestem a mesma figura que o filósofo; pois a sofística é sabedoria aparente, e os dialéticos dialetizam acerca de todas as coisas, e a todos é comum o ente; mas evidentemente, dialetizam sobre essas coisas porque são próprias da filosofia; a sofística e a dialética, com efeito, giram em torno ao mesmo gênero que a filosofia; mas esta difere de um pelo modo da força, e da outra pela escolha de vida; e a dialética é tentativa daquelas coisas de que a filosofia é cognoscitiva, e a sofística é aparente, mas não real”.

8 Terminada a revisão deste texto, tive notícia da obra de Maria José Vaz Pinto, A doutrina do logos na sofística (Lisboa: Colibri, 2001), a qual infelizmente não pude consultar.

\section{REFERÊNCIAS BiBLIOGRÁFICAS}

ARISTÓTELES. La interpretación. Ética Nicomaquea. Metafísica. Poética. Política. Retórica. Analítica posterior. Tópicos. In: Obras. Trad. Francisco de P. Samaranch. Madrid: Aguilar, 1993.

. Les réfutations sophistiques. Trad. Louis-André Dorion. Paris: Vrin, 1995.

. Poética. Trad. Eudoro de Sousa. 3. ed. Lisboa: IN-CM, 1992.

. Poética de Aristóteles. Ed. trilingüe por Valentín García Yebra. Madrid: Gredos, 1974.

. Retórica. Trad. Manuel Alexandre Júnior; Paulo Farmhouse Alberto; Abel do Nascimento Pena. Lisboa: IN-CM, 1998.

CASSIN, Barbara. L'effet sophistique. Paris: Gallimard, 1995.

DIO CHRYSOSTOM, The eleventh discourse maintaining that Troy was not captured. In: Discourses. Trad. J.W. Cohoon. The Loeb Classical Library, 1971, 5 v., v.I.

GÓRGIAS. Elogio de Helena. Sobre o não-ser. In: Testemunhos e fragmentos. Trad. Manuel Barbosa e Inês de Ornellas e Castro. Lisboa: Colibri, 1993.

. Sobre o não-ente. Elogio de Helena. Trad. Maria Cecília de Miranda N. Coelho. Cadernos de Tradução 4, 1999. Departamento de Filosofia da USP, São Paulo.

LICHTENSTEIN, Jaqueline. A cor eloqüente. São Paulo: Siciliano, 1994.

PLUTARCH, On the fame of the Athenians. In: Moralia. Trad. F.C. Babbitt. The Loeb Classical Library, 1962, 15 v., v.Iv. 
MUHANA, Adma. Encomium of Gorgias.

RESUME: The aim of this text is to clarify some of the relations established by Aristotle between poetry, rethoric and sophistic, mainly in The Poetics, The Art of Rethorics and On Sophistical Refutations, contrasting these concepts with what can be inferred from the writings of Gorgias, especially the Encomium of Helen. The starting point is a list of procedures of the language, i.e., from lexis and not logos, that Aristotle, both in The Poetics and in On Sophistical Refutations, identifies as being different from those of dialectics. In both works the list of procedures is the same, but in The Poetics they are legitimated in terms of the elocutive property of poetry and in $\mathrm{On}$ Sophistical Refutations they are rejected as being part of sophistic fallacies.

KEY WORDS: sophistic; rethoric; dialectics; poetics. 